\title{
PENGARUH SKARIFIKASI BIJI DENGAN PERLAKUAN AIR PANAS, MEKANIK DAN ASAM TERHADAP KEMUNCULAN BIBIT DAN PERTUMBUHAN AWAL LAMTORO (Leucaena leucocephala)
}

\author{
Muhammad Rusdy \\ Fakultas Peternakan Universitas Hasanuddin, Makassar, Indonesia \\ E-mail: muhrusdy79@yahoo.co.id
}

\begin{abstract}
The effects of hot water, mechanical and acid scarifications on seedling emergence and early growth of Leucaena leucocphala were studied. The results of various seed scarification methods revealed that all seed scarification pre-treatments improved seedling emergence and early growth of Leucaena. Soaking the seeds with sulfuric acid for 20 and 24 minutes resulted in the highest seedling emergence, plant height, number of leaves, biomass dry weight and the lowest emergence index, followed by mechanical scarification by clipping the seeds around the micropyle and the soaking the seeds in hot water for two minutes. The lowest seedling emergence and early growth of Leucaena were found in control. It can be concluded that seed scarification is needed to improve seedling emergence and early seedling growth of Leucaena leucocephala with acid scarification is the best method.
\end{abstract}

\begin{abstract}
ABSTRAK
Pengaruh skarifikasi dengan air panas, mekanik dan asam terhadap kemunculan bibit dan pertumbuhan awal lamtoro (Leucaena leucocephala) diteliti. Hasil berbagai metoda skarifikasi biji menunjukkan bahwa semua metoda skarifikasi yang digunakan memperbaiki kemunculan dan pertumbuhan awal Lamtoro. Perendaman biji di dalam asam sulfat selama 20 dan 24 menit menghasilkan persentase kemunculan bibit, tinggi tanaman, jumlah daun, biomassa bahan kering tertinggi dan indeks kemunculan bibit terendah, disusul dengan skarifikasi mekanik dengan pemotongan biji pada bagian mikropil dan perlakuan air panas temperatur $80^{\circ} \mathrm{C}$ selama dua menit. Kemunculan bibit dan pertumbuhan awal Lamtoro terendah diperoleh pada kontrol. Dapat disimpulkan bahwa skarifikasi biji dibutuhkan untuk memperbaiki kemunculan dan pertumbuhan awal bibit Lamtoro dengan skarifikasi asam merupakan metode terbaik, walaupun dari sudut pandang petani, karena kesulitan penanganan dan biaya yan tinggi mungkin bukan merupakan metode terbaik.
\end{abstract}

\section{PENDAHULUAN}

Di Indonesia, luas keseluruhan padang rumput, baik rumput alam maupun padang penggembalaan buatan mencapai 80 juta hektar dan daerah ini merupakan 
habitat sekitar $80 \%$ sapi merumput. Luasan tersebut makin lama makin menyempit, terutama karena telah dikonversi menjadi lahan tanaman pangan dan perkebunan. Pada saat sekarang, lahan tersebut mengalami degradasi yang ekstensif, terutama akibat penggembalaan berlebih dan kondisi iklim yang ekstrim. Penggembalaan berlebihan mengakibatkan terjadinya erosi yang cepat yang menurunkan produktivitas dan keaneka-ragaman hijauan yang penting dan berkontribusi terhadap proliferasi gulma yang tidak palatabel bagi ternak.

Salah satu cara untuk mengatasi masalah ini adalah dengan menanam lahan penggembalaan tanaman yang tahan stress, dapat menyuburkan tanah, mempunyai potensi bahan kering tinggi dan bernilai gizi tinggi seperti Lamtoro. Ray et al. (1995) menganjurkan mengintroduksi tanaman ini ke dalam padang penggembalaan untuk meningkatkan produktivitas dan kontinuitas produksinya.

Lamtoro adalah tanaman multi-guna yang cepat tumbuh. Tanaman ini sangat berguna sebagai tanaman penyubur tanah karena kesanggupannya menfiksasi $\mathrm{N}$ dari udara (74 - 584 kg/tahun) (Anonim., 1977; Nutman, 1980). Lamtoro juga terkenal karena tingginya potensi biomassa dan nilai gizinya. Produksi bahan keringnya dapat mencapai 30 ton bahan kering/ha/tahun, tergantung pada kesuburan tanah dan curah hujan (Shelton dan Brewbaker, 1998). Daun Lamtoro disukai ternak, mengandung protein tinggi $(15-38 \%)$ dan tinggi daya cernanya. Protein kasar daun sangat tinggi kualitas nutrisinya, dapat disamakan dengan yang dikandung dalam kedele (U ter Meulen et al. (1985). Walaupun keberadaan mimosin dalam kadar tinggi membatasi pengunaanya sebagai makanan ternak, ternak ruminansia di berbagai bagian dunia seperti Indonesia dan Hawaii dapat mentolerir penggunaan lamtoro dalam proporsi besar karena adanya bakteri tertentu di dalam rumennya yang dapat memecah mimosin menjadi senyawa yang tidak berbahaya bagi ternak (Jones dan Megarrity, 1983).

Walaupun kepentingannya sangat besar, pertumbuhan awal lamtoro sangat sulit. Salah satu faktor pembatas untuk memperoleh pertumbuhan awal yang baik adalah banyaknya biji yang keras yang mengakibatkan biji sulit ditembus air yang harus dipecahkan untuk memudahkan air dan oksigen memasuki embrio dan memulai 
proses perkecambahan. Tanpa skarifikasi, hanya $10 \%$ biji lamtoro yang dapat berkecambah. Penelitian ini dilakukan dengan tujuan menentukan pengaruh skarifikasi dengan air panas, mekanik dan asam terhadap kemunculan bibit dan pertumbuhan awal lamtoro.

\section{MATERI DAN METODE}

Penelitian dilakukan pada di laboratorium lapangan I. Tanaman Pakan dan Pastura Fakultas Peternakan Universitas Hasanuddin Makassar $\left(15^{\circ} 10^{\prime}\right.$ LS $119^{\circ} 20^{\prime}$ BT). Biji-biji lamtoro dipanen dari tanaman yang tumbuh secara alamih di kampus Universitas Hasanuddin. Sebelum digunakan, biji-biji tersebut direndam di dalam air selama lima menit dan hanya biji yang tenggelam yang dipilih untuk penelitian. Penelitian disusun dalam rancangan acak lengkap dengan 15 perlakuan dan tiga ulangan. Perlakuan adalah: 1. kontrol (T1), perendaman biji dalam air panas $\left(80^{\circ} \mathrm{C}\right)$ selama 2, 4, 6 dan 8 menit (T2, T3, T4 dan T5), pemotongan biji $1-2 \mathrm{~mm}$ di bagian mikrofil, 1 - 2 mm di bagian ujung biji dan penggosokan dengan kertas pasir selama 10 menit (T6, T7, dan T8) dan perendaman biji di dalam asam sulfat pekat (96\%) selama 4, 8, 12, 16, 20 dan 24 menit (T9, T10, T11, T12, T13, T14 dan T15).

Sebanyak 20 biji telah diskarifikasi ditanam ke dalam pot-pot (tinggi $14 \mathrm{~cm}$, diameter bawah $12 \mathrm{~cm}$ dan diameter atas $14 \mathrm{~cm}$ ) yang telah diisi penuh tanah dengan kedalaman tanam $2 \mathrm{~cm}$. Tanaman dalam pot disiram seperlunya. Kemunculan bibit dicatat tiap hari sampai hari ke-10 ketika semua bibit sudah muncul di permukaan tanah. Bibit dijarangkan menjadi lima tanaman per pot sesudah perkembangan kotiledon yang sempurna dicapai. Penelitian berakhir pada hari ke-22 setelah tanam, ketika kotiledon menguning. Parameter yang diukur adalah persentase kemunculan bibit, indeks kemunculan bibit, tinggi tanaman, jumlah daun dan berat kering tanaman. Indeks kemunculan bibit (IK) dihitung dengan menggunakan rumus: IK = (TiNi/S), dimana: Ti adalah jumlah hari setelah tanam, Ni adalah jumlah bibit yang muncul pada hari ke Ti dan S adalah jumlah biji yang ditanam. 


\section{HASIL DAN PEMBAHASAN}

Berbagai parameter yang berhubungan dengan kemunculan bibit dan pertumbuhan awal lamtoro dipengaruhi secara nyata oleh perlakuan yang diterapkan. Pada umumnya, dibandingkan dengan control, semua metode skarifikasi biji mempunyai pengaruh yang positif (Tabel 1).

Tabel 1.Pengaruh skarifikasi dengan air panas, mekanik dan asam terhadap persentase kemunculan bibit dan pertumbuhan awal lamtoro

\begin{tabular}{cccccc}
\hline Perlakuan & $\begin{array}{c}\text { Persentase } \\
\text { kemunculan } \\
\text { bibit }(\%)\end{array}$ & $\begin{array}{c}\text { Indeks } \\
\text { kemunculan } \\
\text { bibit }\end{array}$ & $\begin{array}{c}\text { Tinggi } \\
\text { tanaman } \\
(\mathrm{cm})\end{array}$ & $\begin{array}{c}\text { Jumlah daun } \\
\text { (per tanaman) }\end{array}$ & $\begin{array}{c}\text { Berat kering } \\
\text { (g/pot) }\end{array}$ \\
\hline P1 & 9,0 & 0,33 & 6,02 & 3,88 & 0,30 \\
P2 & 49,0 & 3,51 & 6,49 & 4,00 & 0,36 \\
P3 & 46,0 & 4,16 & 6,51 & 4,00 & 0,36 \\
P4 & 40,0 & 6,41 & 6,30 & 3,93 & 0,33 \\
P5 & 37,0 & 8,41 & 5,30 & 3,63 & 0,32 \\
P6 & 58,0 & 2,56 & 7,06 & 4,40 & 0,48 \\
P7 & 54.0 & 2,28 & 6,80 & 4,20 & 0,48 \\
P8 & 52,0 & 2,33 & 7,00 & 4,13 & 0,45 \\
P9 & 50,0 & 3,34 & 7,27 & 4,33 & 0,38 \\
P10 & 54,0 & 3,38 & 7,40 & 4,50 & 0,40 \\
P11 & 58,8 & 3,45 & 7,45 & 4,60 & 0,52 \\
P12 & 64,0 & 2,48 & 7,50 & 4,60 & 0,54 \\
P13 & 66,0 & 2,44 & 7,54 & 4,80 & 0,50 \\
P14 & 66,0 & 2,54 & 7,41 & 4,60 & 0,49 \\
P15 & 60,0 & 2,50 & 6,33 & 4,10 & 0,48 \\
BNT 5\% & 7.43 & 1.05 & 1.28 & 1.80 & 0.08 \\
\hline
\end{tabular}

\section{Skarifikasi air panas}

Skarifikasi dengan air panas mempunyai pengaruh positif terhadap pemecahan dormansi biji pada lamtoro. Kemunculan bibit dan pertumbuhan awal terjadi ketika biji-biji direndam di dalam air panas selama 2 menit (Tabel 1). Hasil yang berbeda dilaporkan oleh Telsa et al. (2000) dan Akinola et al. (1999). Mereka menyatakan bahwa dengan skarifikasi dengan air panas temperatur $80^{\circ} \mathrm{C}$, waktu perendaman yang terbaik yang menghasilkan perkecambahan dan kemunculan bibit 
tertinggi masing-masing adalah 5 dan 10 menit. Hal ini mungkin disebabkan karena perbedaan umur biji yang dipakai dalam penelitian, dimana mereka menggunakan biji yang sudah tua sedangkan pada penelitian ini, digunakan biji segar yang baru dipanen. Diduga bahwa dengan skarifikasi air panas, kemampuan embrio untuk menembus kulit biji menadi lebih besar. Hal ini sesuai dengan yang dikemukakan oleh Anonim. (2017) bahwa dengan ketuaan, daya hidup embrio menurun dan kemampuan berkecambahnya makin rendah.

Lama perendaman optimum dalam air panas juga dipengaruhi oleh tempareatur air. Villierd (1972) melaporkan bahwa pada temperatur air $70^{\circ} \mathrm{C}$, lama perendaman yang terbaik untuk memecah dormansi biji dan mendorong perkecambahan dan kemunculan bibit adalah 20 menit.

Kesuksesan megatasi kekerasan biji dengan air panas juga telah dilaporkan pada berbagai spesies lain, seperti Chrysophyllum albidum (Aduradola et al., 2005), Acacia senegal (Nuhu et al., 2013) dan Vitex agnus cactus L. (Travios dan Karamanos, 2007). Perlakuan air panas telah dilaporkan memperbaiki perkecambahan biji melalui pengaruhnya terhadap berbagai faktor seperti kemudahan air dan oksigen untuk menembus kulit biji dan pembebasan zat-zat penghambat perkecambahan (Sharma et al., 2008).

\section{Skarifikasi mekanis}

Skarifikasi mekanis memperbaiki kemunculan bibit dan pertumbuhan awal lamtoro. Kemunculan bibit dan pertumbuhan awal yang tertinggi didapatkan pada biji yang dipotong sedalam $1-2 \mathrm{~mm}$ di bagian mikropil (Tabel 1). Hasil penelitian ini sesuai dengan Tadros et al. (2011) bahwa pemotongan ujung biji dengan pisau sangat efektif untuk memecahkan dormansi biji pada lamtoro dan itu lebih efektif dari pada skarifikasi dengan kertas pasir (sand paper). Tingginya kemunculan bibit akibat pemotongan biji pada bagian mikropil dan ujung biji juga telah dilaporkan pada tanaman lain seperti Spondias mombin (Oyebamiji et al., 2001) dan Myrica esculenta (Bhatt dan Dar, 2000). Zubairu (2014) menyatakan bahwa dengan adanya lubang 
pada bagian mikropil dan ujung biji, memungkinkan air dan gas-gas termasuk oksigen memasuki embrio sehingga biji dapat berkecambah dengan cepat.

\section{Skarifikasi asam}

Skarifikasi dengan asam mendorong kemunculan bibit dan pertumbuhan awal lamtoro. Kemunculan bibit, tinggi tanaman, jumlah daun dan berat kering paling tinggi ketika direndam dalam asam sulfat selama 20 dan24 menit (Tabel 1). Perbandingan antara ketiga jenis skarifikasi biji menunjukkan bahwa secara umum, kemunculan bibit dan pertumbuhan awal lamtoro paling baik ketika biji direndam alam asam sulfat,disusul dengan skarifikasi mekanik dan skarifikasi air panas. Hasil ini sesuai dengan yang dikemukakan oleh Duguma et al. (1998) bahwa skarifikasi dengan asam sulfat pekat merupakan metoda yang paling efektif untuk memperbaiki permeabilitas kulit biji lamtoro.

Tingginya efek perangsangan asam sulfat terhadap perkecambahan dan kemunculan bibit juga telah dilaporkan pada tanamn lain seperti Tamarindus indica (Muhammad dan Amusa, 2003), Dacryodes edulis (Agbokidi et al., 2007), Atriplex canescens (Nostrat et al., 2008) dan Centrosema pubescens (Rusdy, 2015).

Perbaikan yang signifikan terhadap kemunculan bibit dan pertumbuhan awal lamtoro akibat pemberian asam sulfat menunjukkan bahwa asam sulfat merangsang perkecambahan yang cepat dan seragam. Hal itu mungkin disebabkan karena

perlakuan asam menghilangkan lapisan wax dari kulit biji melalui dekomposisi kimia seperti proses pemecahan seperti yang terjadi pada serangan mikroba (Dachung dan Verinumbe, 2006). Asam sulfat diketahui merusak kulit biji dan membuat lumen selsel mikroskleroid terbuka, yang memungkinkan terjadinya imbibisi air yang mendorong pembebasan gula-gula sederhana yang dengan mudah digunakan untuk sintesis protein dan oleh karena itu menorong perkecambahan (Jackson, 1994).

\section{KESIMPULAN}

Penelitian ini menunjukkan bahwa skarifikasi dengan air panas, mekanik dan asam sulftat secara signifikan memperbaiki kemunculan bibit dan perumbuhan awal 
lamtoro, dengan perlakuan asam memberikan hasil terbaik. Karena asam sulfat harganya mahal dan memerlukan kehati-hatian dalam penggunannya dan perlakuan mekanis dengan memotong biji di bagian ujung tidak praktis, penggunaan air panas mungkin merupakan metoda terbaik di tingkat petani kecil.

\section{DAFTAR PUSTAKA}

Alderate-Chaves, A.,.Guevara-Santos E and Guevara, E. 2011. Effects of scarification chemical treatment on the germination of Crotolaria retusa L. seeds. J. Biol. Sci. 10 : 541 - 544.

Aduradola, A.M., Adeola, B.F., and Aderire, M.O., 2005. Enhancing germination in seeds of African star apple, Chrysophyllum albidum (G. Don). J. Food Agric. Env. 3 (2) : $292-294$.

Agbogidi, O.M., Bosah, B.O., and Eshegbeyi, O.F., 2007. Effect of acid pretreatment on the germination and seedling growth of African pear (Dacryodes edulis Don. G. Lam. H.J.). Int. J.Agric. Res. 2 : 952 - 958.

Akinola, J.O., Iji, P., Bonidefaiye, S.O., and Olorunju, S., 1999. Studies on seed germination and seedling emergence in Leucaena leucoephala (Lam.) de Wit cv. Peru. Seed Sci. Technol. 27 (1) : 123 - 129.

Anonymous, 1977. Leucaena, Promising Forage and Tree Crops for the Tropics. National Academy of Sciences. Washington.

Anonymous, 2017. How does the age of seed affect its ability to germinate ?. http://homeguides.sfgate.com/age-seed-affect-its-ability-germinate-69423.html. Retrieved on April21, 2017

Bhatt, I.D., and Dhar, U., 2000. Improvement in seed germination of Myrica esculenta Buch.-

Ham. Ex. D. Don. Native Plants, $11: 5-10$.

Can, E., Celiktas, N., Hatipoglu, R. and Avci, S., 2009. Breaking seed dormancy of some annual Medicago and Trifolium species of different treatments. Turk. J. Crops, $14: 72-78$.

Martin, I., and De la Cuadra, 2004. Evaluation of different certification methods to remove hardseedness in Trifolium subterraneum and Medicago polymorpha accessions of the Spanish base genebank. Seed Sci. Technol., 32:671-681. 
Dittus, D.A. and Muir, J.P. 2010. Breaking germination dormancy of Texas native perennial herbaceous legumes.

Dachung, G., and Verinumbe, I., 2006. Effect of water and acid pre-treatment on the germination of Prosopis africana seeds. Proceedings of the $31^{\text {st }}$ Annual Conference of the Forestry Association of Nigeria. November $20-25$, Makurdi, pp. $11-18$.

Duguma, B., Kaiw, B.T., and Okali, D.D.U., 1988. Factors affecting germination of Leucaena leucocephala. Seed Sci. Technol. $16: 489$ - 500.

Filho, S., Franca, E.A., and Innecco, R., 2002. Germinacao de sementes de Operculina macrocarpa (L.). Revista Brasileira de Sementes, 24 (2) : 102 - 107.

Gutteridge, R.C. and Shelton, H.M., 1998. Forage Tree Legumes in Tropical Agriculture. Tropical Grassland Society of Australia, Inc.

Jackson, M.B., 1994. Root to shoot communication in flooded plants: involvement of abscisic acid,ethylene and 1-aminopyclopropane-1-carboxylic acid. Agron. J. $86(5): 775-781$.

Jones, R.J., Megarrity, R.G., 1983. Comparative toxicity responses of goats fed on Leucaena leucocephala in Australia and Hawaii. Aust. J. Agric. Res. 34 : 781 790.

Mabberley, D.J. 1997. The plant book: A portable dictionary of the vascular plant. Cambridge University Press.

Maher,T., Nezar, S., and Ahmad, A., 2011. Effect of different pre-sowing seed treatments on the germination of Leucaena leucocephala (Lam.) and Acacia farnesiana (L.). New Forest, 42 (3) : 397 - 407.

Muhammad, S., and Amusa, N.A. 2003. Effects of sulfuric acid and hot water treatments on seed germination $\mathrm{n}$ of tamarind (Tamarindus indica L.). Afr. J. Biotechnol. 2 (9) : $276-279$.

Nuhu, B., Yusuf, Z., Hapsatu, S., and Ishiyaka, I.A., 2013 : Effect of hot water treatment and temperature on seedling emergence and morphological attributes of Acacia senegal L. seeds. J. Agric. Res. Develop. 12 (1) :

Nutman, P.S., 1980. IBP field experiments on nitrogen fixation by nodulated legumes. In: Symbiotic Nitrogen Fixation in Plants, pp. 211 - 237. Nutman, P.S. (ed.), Cambridge Univ., Press. London. 
Oyebamiji, N.A., Fadimu, O.Y., and Adediro, M.O., 2014. Best pre-germination techniques on Spondias mombin Linn, seed for plantation establishment. A. Eur. J. Agric. Environ. Sci. 14 (6) : 575 - 579.

Ray, P., Roy R.D., and Rao G.R., 1995. Evaluation of multipurpose tree species in rangeland under semi arid condition of Uttar Pradesh. J. Range Mgmt \& Forest., 16 (2) : $103-113$.

Rusdy, M. 2015. Enhancing seed germination in seeds of Centrosema pubesens. Int. J. Sci. Res. Pub. 5 (10) : $1-4$.

Rusdy, M. 2016. Improvement of seed germination and early seedling growth of Leucaena leucocephala by cold water, mechanical and acid scarification pretreatment. Int. J. Res. Sci. Pub. 1 (1) : $1-6$.

Rutar, M., Stjepanovic, Popovic, S., Bukvic., and Pacek, D., 2001. Effect of temperature on germination of hard alfalfa seed. CIHEAM, $2: 137-139$.

Scott, S.J., Jones, R.A., and William, W.A., 1984. Review on data analysis methods for seed germination. Crop Sci., 24 : $1192-1199$.

Sharma, S.,Naithani, R., Varghese, B., Keshavkant, S., and Naithani, S.C., 2008. Effect of hot water treatment on seed germination of some fast growing tropical tree. Trop. Forest. 24 (3\& 4) : $49-53$.

Shelton, H.M. and Brewbaker, J.L. 1998. Leucaena leucocephala - the Most Widely Used Forage Tree Legume Species. In: Forage Tree Legumes in Tropical Agriculture. Ed. by R.C. Gutteridge and H.M. Shelton, The University of Queensland, Australia.

Shibata, T. and Y. Hatakeyama, 1995. Breaking of dormancy in seeds of Astragalus mongholicus Bunge (Leguminosae). J. Plant Physiol., 146 : 366 - 368.

Stout, D.G., 1990. Effect of freeze thaw cycles on hardseedness of alfalfa J. Seed Technol., $14: 47-55$.

Teles, M.M., Alves, A.A., Oleivera, J.C.G de, and Bezerra, A.M.E., 2000. Procedure for dormancy breakage in Leucaena leucocephala. Revista Brasileira de Zootecnia, 29 (2) :387 - 391.

Tomer, R. and Meguire, J.D., 1989. Hard seed studies in alfalfa. Seed Res., 17 : 29 31 . 
Travios, I.S., and Karamanos, A.J. 2007. Influence of heat on seed germination and seedling emergence of Chaste tree (Vitex agnus cactus L.). Journal of Agronomy, $6: 25-28$.

Villiers, T.A., 1972. Cytological studies in dormancy. I. Embryo maturation during dormancy in Fraxinus excelsior. In: Seed Biology, T.T. Kozlowski (ed.) 11, A.P.

Zare, S., A Tavili,.and M.J Darini,. 2011. Effects of different treatments on seed germination and breaking seed dormancy of Prosopis koelziana and Prosopis juliflora. J. Forest. Res. 22 (1) : $35-38$.

Zubairu, S.U., 2014. The influence of pre-treatments on seed germination and seedling vogor in Acacia senegal in the nurse. J. Biol. Agric. Healthcare, 4 (12) $: 57-62$. 